\title{
International Students' Mental Health Care in China: A Systematic Review
}

\author{
Yanping $\mathrm{Wu}^{1}{ }^{1}$, Wuqianhui Liu ${ }^{2}$, Aijun Liu ${ }^{3, *} \mathbb{C}$, Li Lin-Schilstra ${ }^{3}$ and Ping Lyu ${ }^{1}$ \\ 1 School of Overseas Education, Nanjing Xiaozhuang University, 41 Beiwei Road, Nanjing 210017, China; \\ wuyanping@njxzc.edu.cn (Y.W.); lyuping@njxzc.edu.cn (P.L.) \\ 2 The First School of Clinical Medicine, Nanjing Medical University, Nanjing 211166, China; \\ liuwqh@njmu.edu.cn \\ 3 College of Economics and Management, Nanjing Agricultural University, 1 Weigang, Nanjing 210095, China; \\ li.lin@njau.edu.cn \\ * Correspondence: liuaj@njau.edu.cn
}

Citation: Wu, Y.; Liu, W.; Liu, A.; Lin-Schilstra, L.; Lyu, P. International Students' Mental Health Care in China: A Systematic Review. Healthcare 2021, 9, 1634. https:// doi.org/10.3390/healthcare9121634

Academic Editor: Ilaria Baiardini

Received: 20 October 2021

Accepted: 22 November 2021

Published: 25 November 2021

Publisher's Note: MDPI stays neutral with regard to jurisdictional claims in published maps and institutional affiliations.

Copyright: (C) 2021 by the authors. Licensee MDPI, Basel, Switzerland. This article is an open access article distributed under the terms and conditions of the Creative Commons Attribution (CC BY) license (https:// creativecommons.org/licenses/by/ $4.0 /)$

\begin{abstract}
International students in China are facing difficulties while adapting their Chinese culture and their life is influenced by the widespread of the Coronavirus Disease 2019 (COVID-19), and caring for their mental health is currently challenging. As a result, our aim is to explore the current mental health care of this minority in China and to provide useful suggestions for future research and institutes. We used the systematic review method, and it was conducted on 11 existing pieces of literature. Our results confirm the unsatisfying psychological situation of international students and the lack of research in this area. We focus on the causes and symptoms of mental problems and explore the effectiveness of methods.
\end{abstract}

Keywords: systematic review; mental health; international students; China

\section{Introduction}

As China's international education is progressing, this country has been a hotspot for international students, and the number of international students who study in China is constantly increasing. In 2018, there were 492.185 international students from 196 countries in China, among which 59.95\% from Asia, $16.57 \%$ from Africa, $14.96 \%$ from Europe, $7.26 \%$ from America and $1.27 \%$ from Oceania [1]. International students contribute to the diversity in Chinese Universities and China's international reputation. Additionally, international students have proven valuable in the study of cultural adaptation and other culture-related studies. However, this minority's mental situation has not been paid enough attention to. Various factors contribute to the occurrence of mental diseases in international students, including loneliness, isolation and acculturative stress. Particularly, as the widespread of the Coronavirus Disease 2019 (COVID-19) continues to aggravate, quarantine measures have been adopted, and international students' life in China has been greatly affected during the lockdown. The undeniable impact of COVID-19 on mental health worldwide is causing concern among researchers since the pandemic has led mental diseases, including depression and obsessive-compulsive disorder (OCD) [2], to exacerbate. It is estimated that $13.5 \%$ of medical students in China have reported moderate-severe depression even before the pandemic, which indicates an urgent need to handle the problem [3]. International students are vulnerable to various mental diseases, including depression and anxiety $[4,5]$. Moreover, especially during the pandemic, the Chinese healthcare system is impacted, which brings obstacles to foreigners since many hospitals are shut down or limit the number of patients. International students in this country, however, have received a lack of attention. It is also reported that foreign students in China are suffering from helplessness and increasing anxiety of COVID-19 [6]. As a result, it is indispensable to focus on international students in China because they have to not only suffer from 
acculturative stress [7] and struggle to adapt to the Chinese culture but also face the great challenges to deal with the epidemic as well. Therefore, we intend to investigate their mental situation and coping strategies based on existing literature during and before the prevalence of COVID-19 and provide suggestions to institutes and clinicians on the prevention of mental diseases of international students in China.

\section{Method}

In this article, we use the systematic review method to summarize the current process of studying the international students' mental health situation in China. We did not adopt the meta-analysis method for the diversity of mental problems and personal differences among international students in China.

\subsection{Searching Strategy}

We adopt the systematic review method to present studies on the mental health of international students in China. We only included articles that are written in English. Considering the novelty of this theme, we set no time filter, and the earliest article adopted was published in April, 2014. The database review was completed in August, 2021. Pubmed, the Web of Science Core Collection, Medline and Google Scholar are included in the searching process. We choose keywords as follows when proceeding the database research: international student (international student*, foreign student $t^{*}$ ) in China and mental health (depression, anxiety, disorder*, psycho*). Finally, we found 90 articles. Among them, 86 were found on PubMed, 2 were found on Google Scholar and 2 were found on Web of Science. After removing duplicates, 86 articles were retained. Other study material, for example, the consequences brought by acculturative stress, were collected from PubMed.

\subsection{Inclusion and Exclusion Criteria}

In total, 86 articles were found. Initially, we removes articles that focused on Chinese international students $(n=46)$ and local students in Chinese universities $(n=22)$. Further, articles are excluded if they: (1) explore new methods to conduct education without referring to psychological aspects $(n=3)$; (2) focus on physical problems $(n=1)$; (3) focus on international students in other countries $(n=2) ;(4)$ are letters to the Editor $(n=1)$. Finally, 11 articles were included. Figure 1 demonstrates the process of including and excluding articles. 

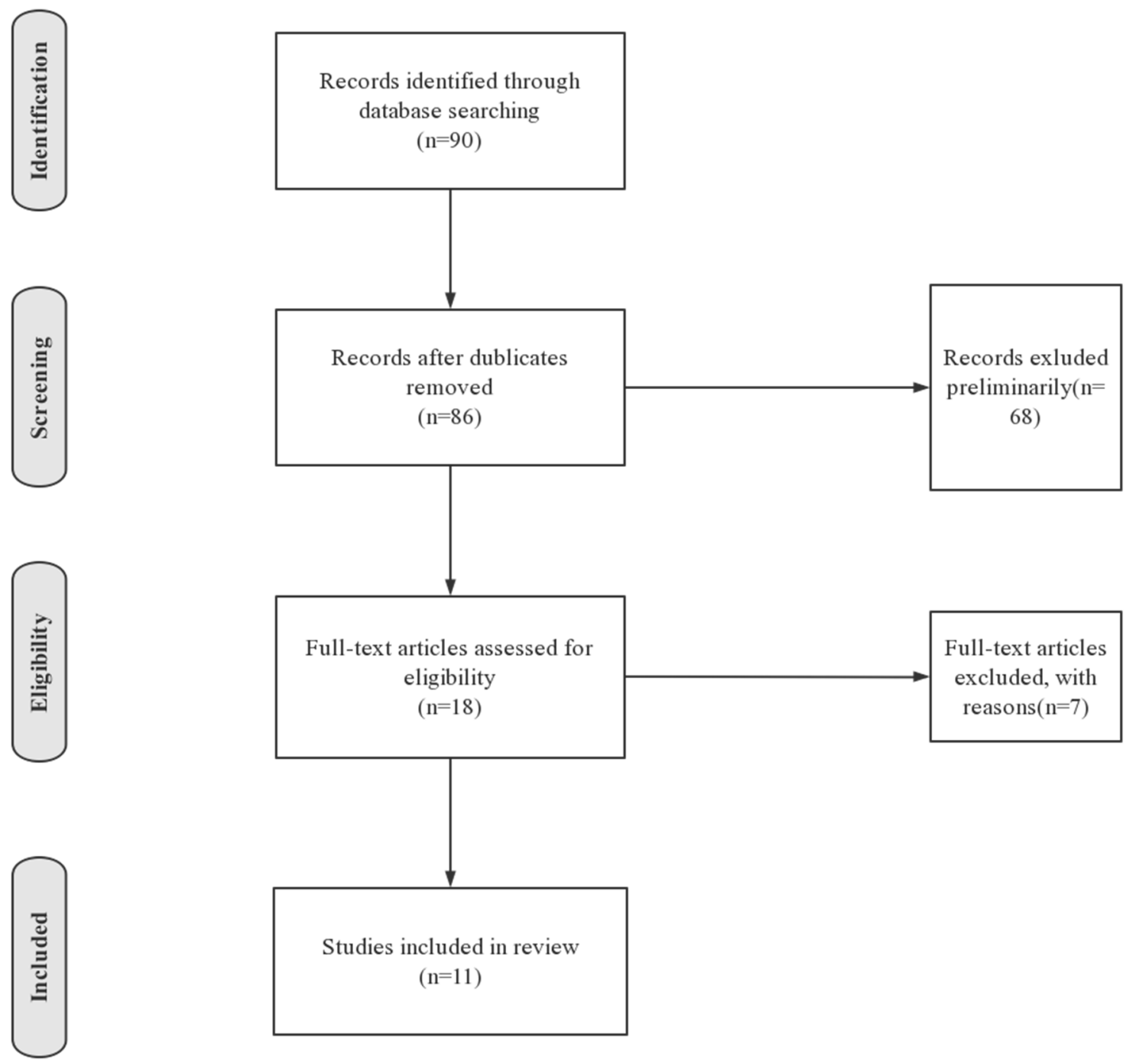

Figure 1. Flow diagram for the process of searching existing literature.

\section{Results}

\subsection{Study of Mental Health Problems and Related Factors}

In total, after excluding 4 duplications and 75 unqualified researches, 11 articles were identified [7-17]. Among them, two investigated the learning condition and mental situation of international students in China under COVID-19 [15,17]. One focused on the psychological barriers that influence the efficiency of online education [15]. Four specifically explored depression among various mental health problems $[9,12,14,17]$, and eight referred to depression [7-12,14,15]. Loneliness is also a hot issue and is investigated in two articles [8,11]. Two articles chose acculturative stress as their theme [7,12]. All studies are cross-sectional. Table 1 shows the details of all 11 articles. 
Table 1. Data extraction of included studies.

\begin{tabular}{|c|c|c|c|c|c|c|}
\hline Author and Year & Purpose & Data Sources & $\begin{array}{c}\text { Study } \\
\text { Design/Sample } \\
\text { Size }\end{array}$ & Control Variables & Measures & Findings \\
\hline $\begin{array}{l}\text { [5] Yu et al., } \\
2014\end{array}$ & $\begin{array}{l}\text { To investigate } \\
\text { acculturative stress } \\
\text { among international } \\
\text { students in China } \\
\text { and the influential } \\
\text { factors behind it }\end{array}$ & questionnaire data & $\begin{array}{c}\text { Cross-sectional/ } \\
n=567\end{array}$ & $\begin{array}{c}\text { country, age, } \\
\text { religion, months } \\
\text { in China, marital } \\
\text { status }\end{array}$ & $\begin{array}{l}\text { Acculturative Stress } \\
\text { Subconstructs }\end{array}$ & $\begin{array}{l}\text { Acculturative stress } \\
\text { is more common in } \\
\text { China than } \\
\text { developed countries } \\
\text { and in students that } \\
\text { are unmarried and } \\
\text { well-prepared and } \\
\text { do not belong to an } \\
\text { organized religion. }\end{array}$ \\
\hline $\begin{array}{l}\text { [6] Jiang et al. } \\
2018\end{array}$ & $\begin{array}{l}\text { To examine the } \\
\text { relationship } \\
\text { between } \\
\text { individualism, } \\
\text { loneliness, } \\
\text { smartphone use and } \\
\text { smartphone } \\
\text { addiction }\end{array}$ & questionnaire data & $\begin{array}{c}\text { Cross-sectional/ } \\
n=438\end{array}$ & country, age & $\begin{array}{c}\text { Hofsted's } \\
\text { Individualism } \\
\text { Index, 32; the UCLA } \\
\text { Loneliness Scale, } \\
26.67 \\
\text { Smartphone } \\
\text { Addiction } \\
\text { Scale-Short version } \\
\text { (SAS-SV).50 }\end{array}$ & $\begin{array}{c}\text { International } \\
\text { students with lower } \\
\text { degrees of } \\
\text { individualism show } \\
\text { higher degrees of } \\
\text { loneliness, which } \\
\text { leads to a higher } \\
\text { degree of } \\
\text { smartphone use and } \\
\text { smartphone } \\
\text { addiction. }\end{array}$ \\
\hline $\begin{array}{l}\text { [7] Liu et al., } \\
2016\end{array}$ & $\begin{array}{l}\text { To investigate the } \\
\text { relationship } \\
\text { between various } \\
\text { components and } \\
\text { depression }\end{array}$ & questionnaire data & $\begin{array}{c}\text { Cross-sectional/ } \\
\quad n=567\end{array}$ & sex, age, country & $\begin{array}{l}\text { Acculturative Stress } \\
\text { Scale for } \\
\text { International } \\
\text { Students; Center for } \\
\text { Epidemiologic } \\
\text { Studies } \\
\text { Short Depression } \\
\text { Scale }\end{array}$ & $\begin{array}{l}\text { The role of } \\
\text { self-confidence in } \\
\text { understanding is } \\
\text { crucial in } \\
\text { acculturative stress } \\
\text { and depression. }\end{array}$ \\
\hline $\begin{array}{l}\text { [8] Ansong et al. } \\
2019\end{array}$ & $\begin{array}{l}\text { To address the } \\
\text { menstrual problems, } \\
\text { together with their } \\
\text { associated risk } \\
\text { factors, among } \\
\text { international } \\
\text { students in China. }\end{array}$ & questionnaire data & $\begin{array}{c}\text { Cross-sectional/ } \\
\quad n=409\end{array}$ & $\begin{array}{l}\text { age, BMI, country, } \\
\text { program }\end{array}$ & $\mathrm{N} / \mathrm{A}$ & $\begin{array}{l}\text { A high level of } \\
\text { stress leads to } \\
\text { menstrual disorders, } \\
\text { and menstrual } \\
\text { disorders rate is } \\
\text { high in } \\
\text { international } \\
\text { students in China. }\end{array}$ \\
\hline $\begin{array}{l}\text { [9] Jiang et al., } \\
2020\end{array}$ & $\begin{array}{l}\text { To explore life } \\
\text { satisfaction of } \\
\text { international } \\
\text { students in China }\end{array}$ & existing literature & $\mathrm{N} / \mathrm{A}$ & $\mathrm{N} / \mathrm{A}$ & $\mathrm{N} / \mathrm{A}$ & $\begin{array}{c}\text { Findings are helpful } \\
\text { for further research, } \\
\text { policy makers and } \\
\text { university } \\
\text { practitioners to } \\
\text { provide high } \\
\text { quality education. }\end{array}$ \\
\hline $\begin{array}{l}\text { [10] Shan et al., } \\
2020\end{array}$ & $\begin{array}{l}\text { To investigate } \\
\text { acculturation stress } \\
\text { among Pakistani } \\
\text { students in China }\end{array}$ & questionnaire data & $\begin{array}{c}\text { Cross-sectional/ } \\
\quad n=203\end{array}$ & $\mathrm{~N} / \mathrm{A}$ & $\mathrm{N} / \mathrm{A}$ & $\begin{array}{c}\text { Orientation lectures, } \\
\text { interaction with } \\
\text { local students and } \\
\text { related activities are } \\
\text { helpful for } \\
\text { international } \\
\text { students. }\end{array}$ \\
\hline $\begin{array}{l}\text { [11] Hu et al., } \\
2016\end{array}$ & $\begin{array}{l}\text { To investigate the } \\
\text { CERQ results and } \\
\text { depressive } \\
\text { symptoms of both } \\
\text { local and } \\
\text { international } \\
\text { students }\end{array}$ & questionnaire data & $\begin{array}{c}\text { Cross-sectional/ } \\
n=255 \text { (foreign } \\
\text { students), } n=262 \\
\text { (Chinese students) }\end{array}$ & age, sex & CERQ; ASLEC; SDS & $\begin{array}{l}\text { Encouraging } \\
\text { students to use } \\
\text { adaptive coping } \\
\text { methods during } \\
\text { psychological } \\
\text { intervention is an } \\
\text { effective way to } \\
\text { adjust cognitions } \\
\text { and behavior. }\end{array}$ \\
\hline $\begin{array}{l}\text { [12] Wang et al., } \\
2020\end{array}$ & $\begin{array}{l}\text { To investigate the } \\
\text { mental health status } \\
\text { of international } \\
\text { students from } \\
\text { Changsha city, } \\
\text { China }\end{array}$ & questionnaire data & $\begin{array}{c}\text { Cross-sectional/ } \\
\quad n=153\end{array}$ & school time, sex, age & $\begin{array}{l}\text { PHQ-9; GAD-7; } \\
\text { SATI }\end{array}$ & $\begin{array}{l}\text { The study implies } \\
\text { that the university } \\
\text { needs to consider } \\
\text { planning for acute } \\
\text { and long-term } \\
\text { psychological help } \\
\text { services for } \\
\text { international } \\
\text { students. }\end{array}$ \\
\hline
\end{tabular}


Table 1. Cont.

\begin{tabular}{|c|c|c|c|c|c|c|}
\hline Author and Year & Purpose & Data Sources & $\begin{array}{c}\text { Study } \\
\text { Design/Sample } \\
\text { Size }\end{array}$ & Control Variables & Measures & Findings \\
\hline $\begin{array}{l}\text { [13] Li et al., } \\
2021\end{array}$ & $\begin{array}{l}\text { To investigate the } \\
\text { influence of social } \\
\text { support on } \\
\text { depression and the } \\
\text { mediation and } \\
\text { moderation } \\
\text { mechanisms among } \\
\text { international } \\
\text { students }\end{array}$ & questionnaire data & $\begin{array}{c}\text { Cross-sectional/ } \\
\quad n=349\end{array}$ & $\mathrm{~N} / \mathrm{A}$ & $\begin{array}{c}\text { Self-Rating } \\
\text { Depression } \\
\text { Scale; Social } \\
\text { Support } \\
\text { Rating Scale }\end{array}$ & $\begin{array}{l}\text { Attachment } \\
\text { closeness has an } \\
\text { effect on depression; } \\
\text { the direct effect of } \\
\text { social support and } \\
\text { the mediating effect } \\
\text { of attachment and } \\
\text { closeness are } \\
\text { regulated by } \\
\text { self-esteem. }\end{array}$ \\
\hline $\begin{array}{l}\text { [14] Gu et al., } \\
2020\end{array}$ & $\begin{array}{l}\text { To investigate the } \\
\text { effects of } \\
\text { mindfulness } \\
\text { training on } \\
\text { depressive } \\
\text { symptoms of } \\
\text { international } \\
\text { students }\end{array}$ & questionnaire data & $\begin{array}{l}\text { Cross-sectional and } \\
\text { panel/ } \\
n=260\end{array}$ & country, sex, major & $\begin{array}{c}\text { Self-Rating } \\
\text { Depression } \\
\text { Scale; Life Event } \\
\text { Test }\end{array}$ & $\begin{array}{l}\text { Mindfulness } \\
\text { training for } 8 \text { weeks } \\
\text { significantly } \\
\text { reduced the } \\
\text { depressive } \\
\text { symptoms. }\end{array}$ \\
\hline $\begin{array}{l}\text { [15] Li et al., } \\
2021\end{array}$ & $\begin{array}{l}\text { To explore the } \\
\text { quality of the online } \\
\text { education in China } \\
\text { for international } \\
\text { medical and } \\
\text { nursing students } \\
\text { from developing } \\
\text { countries }\end{array}$ & questionnaire data & $\begin{array}{l}\text { Cross-sectional/ } \\
n=230 \\
\text { (student), } n=95 \\
\quad \text { (teacher) }\end{array}$ & $\begin{array}{l}\text { major, age, months } \\
\text { in China, sex }\end{array}$ & $\mathrm{N} / \mathrm{A}$ & $\begin{array}{l}\text { The study defines } \\
\text { several factors that } \\
\text { affect the quality of } \\
\text { online education for } \\
\text { international } \\
\text { students. }\end{array}$ \\
\hline
\end{tabular}

SATI: State-Trait Anxiety Inventory; GAD-7: 7-item Generalized Anxiety Disorder-7 Scale H; PHQ-9: the 9-item Patient Health Questionnaire-9; CERQ: The Cognitive Emotion Regulation Questionnaire; SDS: A Self-rating Depression Scale; ASLEC: College Students' Life Events Scale.

Yu et al. [7] examined acculturative stress and its influential factors. Their sample was 567 international students from 97 countries in China, and their data were obtained via the International Student Health and Behavior Survey. They built acculturative stress substructs and analyzed internal and external factors. Their results demonstrated that the acculturative stress level of international students from developing countries in China was about 10 points $(\mathrm{M}=92.81(\mathrm{SD}=23.93)$ vs. $\mathrm{M}=81.39(\mathrm{SD}=24.66)$ or $\mathrm{M}=83.45(\mathrm{SD}=25.05)$ ) higher than it of students from developed countries. Students from African $(M=97.66$, $\mathrm{SD}=23.16)$ and other Asian $(\mathrm{M}=92.54, \mathrm{SD}=22.03)$ countries reported more acculturative stress than students from countries in other continents $(\mathrm{M}=81.19, \mathrm{SD}=27.03)$. They also determined risk and protective factors for acculturative factors, such as preparedness, religion and marrying status.

Jiang et al. [8] investigated the relation among individualism, loneliness and mobile phone addiction. They conducted an online survey, and their sample was 438 international students from 67 countries. The results revealed that individualism $(b=-0.18, p<0.01)$ had significant and negative influences on loneliness, and loneliness $(b=0.14, p<0.01)$ had significant and positive influence on smartphone use. Smartphone use $(b=0.17, p<0.01)$ and loneliness $(b=0.32, p<0.01)$ showed significant and positive effects on smartphone addiction. Therefore, they came to the conclusion that lower individualism leads to higher loneliness, and loneliness contributes to mobile phone addiction. They also discussed advice and implications for further research.

Liu et al. [9] highlighted the central role of self-confidence in understanding acculturative stress and depression and provided new data supporting more effective counselling for international students in China. They extended the research made by Yu et al. [5]. They conducted a questionnaire data collection among 567 international students in Wuhan, China, and adopted the Acculturative Stress Scale for International Students (ASSIS). Their analysis demonstrated a positive relationship between the total ASSIS score and depression ( $\beta=0.101, p<0.01, \mathrm{~F}=143.12, p<0.001)$. Their results also indicated that low cultural competence, homesickness and low self-confidence were significantly and positively associated with depression, and they emphasized the importance of self-confidence in the role of preventing depression. 
Ansong et al. [10] addressed menstrual problems, together with their associated risk factors, among international students in China. This cross-sectional study included 2016 female international students in China. They found out high stress was also significantly associated the risk of dysmenorrhea $(p=0.037)$. This study also indicated that over half $(60.4 \%)$ of the studied population suffer from high stress. As a result, it is necessary to provide support according to other studies, including religion, mental health and cultural background. Their conclusion was that high level stress leads to menstrual disorders, and menstrual disorders rate is high in international students in China.

Jiang et al. [11] aimed to explore life satisfaction of international students in China. This article is a comprehensive review for policies and practice and other reviews from various aspects related to international students in China, along with studies in other countries. They discussed present polices, political factors and the situation of international students. As for psychological aspects, they indicated that a minority of students have mental problems, and many are suffering from loneliness and sadness.

Shan et al. [12] investigated acculturation stress among Pakistani students in China. Their sample was 203 Pakistani university students in China. The ASSIS was adopted. They estimated the degree of acculturative stress among Pakistani students, along with discrimination, homesickness, stress and fear. They finally offered useful suggestions for the improvement of their mental health.

Hu et al. [13] used the Cognitive Emotion Regulation Questionnaire (CERQ), College Students' Life Events Scale (ASELC) and SDS to investigate depression symptoms among university students, both local and international, in China. They conducted a comparison between international and local students between male and female ones. They suggested that compared to Chinese students, international students more often used cognitive adjustment methods. Their conclusion was that positive coping methods lead to the declination of depression and vice versa.

Wang et al. [14] conducted an online survey on the mental health status under COVID19 of international students in Changsha, China. Their study demonstrated that the prevalence of depression was $59.4 \%$, and the prevalence of anxiety was $37.8 \%$. As for students under quarantine, researchers did not find rise in the rate of anxiety and depression. The study suggests that schools need to consider providing short-term and long-term psychological help services for international students.

Li et al. [15] studied the effect of social support on depression and mediation mechanisms in international students. Their study was conducted on 349 international students and their depression extent was evaluated by the SDS and Social Support Rating Scale. The results showed that social support had a significant predictive effect on attachment closeness $(\beta=0.110, p<0.001)$, and the interaction between social support and self-esteem had a significant effect on attachment closeness $(\beta=0.020, p<0.05)$. The effect of social support on depression was significant $(\beta=-0.325, p<0.001)$, and the effect of attachment closeness on depression was also significant $(\beta=-0.305, p<0.05)$. Their conclusion was that in the relationship between social support and depression, self-esteem plays a moderating role in the mediating effect of attachment closeness.

\subsection{Studies of Psychological Measures That Affect Students' Mental Health}

Gu et al. [16] investigated the effects of mindfulness training on depressive symptoms of international students. They adopted the Self-Rating Depression Scale to estimate the depression rate of students. Their results suggest that $33.80 \%$ of their sample have mild depression, $17.84 \%$ of their sample have moderate depression and $5.16 \%$ have severe depression. The mean depression degree of male students and female students was $49.93 \%$ and $42.55 \%$. The mean depression index for all participants was 0.46 , which indicated a mild depression. Having analyzed their depression rate after receiving mindfulness training, they came to the conclusion that mindfulness training and positive coping style are interrelated with treating depressive symptoms for international students. 


\subsection{Studies of Other Measures Adopted during COVID-19 Affecting Students' Mental Health}

Li et al. [17] studied the quality of online education under COVID-19. This study pointed out several crucial factors that influence students' satisfaction of online education. They indicated that international students who are far away from home are vulnerable to mental health problems and advised that schools provide support for international students who stayed in China during the pandemic. Their study mainly focused on both internal and external factors that influence the quality of online education during the quarantine.

\section{Discussion}

\subsection{Mental Health Situation of International Students}

\subsubsection{Depression and Anxiety Symptoms}

We can conclude from the literature included that international students in China have a relatively high rate of depression compared to normal Chinese people, whose depression rate is $2.1 \%$ [18]. According to Wang et al. [14], the prevalence of depression among international students is $59.7 \%$, and according to $\mathrm{Gu}$ et al. [16], the prevalence of it is $56.8 \%$. Those two values are close to each other, increasing the reliability of the results. These suggest an approximately 27 times higher prevalence than ordinary Chinese residents, indicating a serious mental health crisis. Afterwards, China's international students' anxiety level is higher than that in South Korea (49\%) [19]. Acculturative stress, high academical pressure and loneliness probably account for this phenomenon. As can be seen from the results, among all 11 studies, eight only focus on depression and anxiety symptoms, which cover $72.7 \%$ of the studies, and other mental diseases are not involved in researches. However, it is notable that over $2 \%$ of the whole population around the world is suffering from OCD [2], and other severe mental problems, such as schizophrenia and bipolar symptoms, that occupy a certain part of the population. The sole focus on depression and anxiety is a one-sided issue of the picture. Anxiety, OCD and depression have common points and can all be treated with Selective Serotonin Reuptake Inhibitors (SSRIs) [20], suggesting the need of investigating various mental problems, which may also provide a chance to find out the relationship between different mental health problems. Moreover, studies on multiple mental problems may provide more angles to solve students difficulty and to explore the interaction between simple neurosis and complicated mental problems.

\subsubsection{Acculturative Stress}

Acculturative stress is defined as the process of confronting challenges in cross-cultural exchange settings [7], which is one of the multiple adaptation problems for international students [21]. This stress leads to various problems, including alcohol addiction, emotional eating and sleeping obstruction [22-24]. International students are ideal samples to investigate this issue, which is even more obvious in China since this country has students from both developed countries and developing countries. Two studies in this review $([7,12])$ solely focus on this unique problem. Better preparedness is beneficial for the solution of acculturative stress [7,12]. As a result, universities can provide useful lectures about Chinese culture before international students arrive in China or in the orientation courses to make them more well-prepared and to decrease the effect of acculturative stress.

\subsubsection{Variation in Mental Health Situation under COVID-19}

China mainly adopts quarantine measures in order to control the spread of COVID-19, which have proven to be effective [25]. During the lockdown, about $75 \%$ of international students came back to their countries [17]. Nonetheless, international students' life are greatly affected under the strict quarantine measures. According to Wang et al. [14], some international students are quarantined in their dormitories, and the length of quarantine time affects the possibility of having intellectual problems. According to Li et al. [17], other international students staying in their own countries are provided with online courses. 
As a result, they may feel isolated, and their study is not as satisfying as before, and the exacerbation of loneliness occurs [17]. Thus, universities should manage to provide a better learning environment for students staying abroad and, at the same time, offer effective psychological services for all international students. Moreover, further studies are expected on the comparison of the anxiety level of students, both local and foreign, before and after vaccination.

\subsection{Coping Strategies and Implication for Universities, Researchers and Governments}

We can summarize from the analysis presented above that international students' mental health situation is not satisfying, so it is urgent to do more research and improve coping strategies. Two studies $[9,16]$ emphasized the importance of self-esteem and self-confidence in the prevention of depression, which is also supported by $[26,27]$. Teachers may consider giving courses that give rise to an increase in self-confidence. Gu et al. [16] confirmed the usefulness of mindfulness training since it leads to the declination of depression symptoms, which is also supported by McConveille et al. [28]. However, because this is the sole research that provides the evidence of the benefit of adopting psychological measures, it can be deduced that few universities in China conduct psychological courses for international students. Therefore, it is high time that universities improve related services for international students. Psychological teachers' English level should be approved, making it available for international students to counsel. The effect of counseling between Chinese teachers and foreign students should also be tested by other researches. There are totally 11 qualified articles, indicating a need for more research. Research on other meditating methods will be helpful. Additionally, a cross-country comparison is recommended. It can be seen from the results that all studies are cross-sectional. If teachers and clinicians are able to use panel data to investigate students' psychological problems, new angles may be provided.

As for the Chinese government, better policies should be introduced. International students who stay in the mainland may enjoy a discount when buying psychotropic drugs, or the cost may be included in their medical insurance. Moreover, a great many hospitals in China nowadays have international medical centers that provide special services for foreigners, and some hospitals include psychological counseling in these centers. These institutions can be introduced to more hospitals and may cooperate with international centers in colleges. They may promote their services to foreign students at a reasonable price.

\section{Conclusions}

The mental health care of international students in China is not satisfying, and the attention paid to this minority is insufficient. Under COVID-19, variation occurs in their life, and they need to adapt. As can be seen from the results, there is little research in this area. Despite abundant research of depression and anxiety, other diseases are not included. Researches in each aspect are not comprehensive enough. Chinese universities should provide better services for international students. The cooperation between the Chinese government and universities is indispensable for the improvement of international students' mental health. Further research is needed on the interaction among different mental diseases and on more effective measures to improve their mental health. There is still a lot of room for this issue to be improved.

Author Contributions: Conceptualization, Y.W. and W.L.; methodology, W.L; validation, Y.W., W.L. and A.L; formal analysis, A.L.; investigation, Y.W.; resources, L.L.-S.; data curation, L.L.-S.; writingoriginal draft preparation, Y.W.; writing - review and editing, W.L.; visualization, P.L.; supervision, P.L.; project administration, L.L.-S.; funding acquisition, Y.W. and A.L. All authors have read and agreed to the published version of the manuscript.

Funding: The authors acknowledge the research fund sponsorship by the "Jiangsu University Philosophy and Social Science Foundation, grant number 2018SJA0439", "Nanjing Xiaozhuang 
University Research Project, grant number 2021SZKYT05”, “Graduate Course Project of Nanjing Agricultural University, grant number 2020-9", "the 5th Nanjing Agricultural University English Program Projects, grant number 12", “Undergraduates Teaching Reform and Quality Improvement Project of Promotion Committee of Agricultural Economics \& Management of National Universities of MOE, China, Grant No. NJX20112".

Institutional Review Board Statement: Not applicable.

Informed Consent Statement: Not applicable.

Data Availability Statement: No data, models, or code were generated or used during the study.

Conflicts of Interest: The authors declare no conflict of interest.

\section{References}

1. Ministry of Education, China. 2018 Statistics of International Students in China. Available online: http://www.moe.gov.cn/jyb_ xwfb /gzdt_gzdt/s5987/201904/t20190412_377692.html (accessed on 12 October 2021).

2. Liu, W.; Zhang, H.; He, Y. Variation in Obsessive-Compulsive Disorder Symptoms and Treatments: A Side Effect of COVID-19. Int. J. Environ. Res. Public Health 2021, 18, 7420. [CrossRef] [PubMed]

3. Sobowale, K.; Zhou, A.N.; Fan, J.; Liu, N.; Sherer, R. Depression and suicidal ideation in medical students in China: A call for wellness curricula. Int. J. Med Educ. 2014, 5, 31-36. [CrossRef] [PubMed]

4. Alharbi, E.S.; Smith, A.P. Review of the Literature on Stress and Wellbeing of International Students in English-Speaking Countries. Int. Educ. Stud. 2018, 11, 22. [CrossRef]

5. Brunsting, N.C.; Zachry, C.; Takeuchi, R. Predictors of undergraduate international student psychosocial adjustment to US universities: A systematic review from 2009-2018. Int. J. Intercult. Relat. 2018, 66, 22-33. [CrossRef]

6. Kulyar, M.F.-E.-A.; Bhutta, Z.A.; Shabbir, S.; Akhtar, M. Psychosocial impact of COVID-19 outbreak on international students living in Hubei province, China. Travel Med. Infect. Dis. 2020, 37, 101712. [CrossRef]

7. Yu, B.; Chen, X.; Li, S.; Liu, Y.; Jacques-Tiura, A.; Yan, H. Acculturative Stress and Influential Factors among International Students in China: A Structural Dynamic Perspective. PLoS ONE 2014, 9, e96322. [CrossRef]

8. Jiang, Q.; Li, Y.; Shypenka, V. Loneliness, Individualism, and Smartphone Addiction Among International Students in China. Cyberpsychology Behav. Soc. Netw. 2018, 21,711-718. [CrossRef] [PubMed]

9. Liu, Y.; Chen, X.; Li, S.; Yu, B.; Wang, Y.; Yan, H. Path Analysis of Acculturative Stress Components and Their Relationship with Depression Among International Students in China. Stress Health 2016, 32, 524-532. [CrossRef] [PubMed]

10. Ansong, E.; Arhin, S.K.; Cai, Y.; Xu, X.; Wu, X. Menstrual characteristics, disorders and associated risk factors among female international students in Zhejiang Province, China: A cross-sectional survey. BMC Womens Health 2019, 19, 1-10. [CrossRef]

11. Jiang, Q.; Yuen, M.; Horta, H. Factors Influencing Life Satisfaction of International Students in Mainland China. Int. J. Adv. Couns. 2020, 42, 393-413. [CrossRef] [PubMed]

12. Shan, C.; Hussain, M.; Sargani, G.R. A mix-method investigation on acculturative stress among Pakistani students in China. PLoS ONE 2020, 15, e0240103. [CrossRef] [PubMed]

13. $\mathrm{Hu}, \mathrm{H} . ;$ Alsron, B.; $\mathrm{Xu}, \mathrm{B}$; Hao, W. Comparative analysis of results from a cognitive emotion regulation questionnaire between international students from West Asia and Xinjiang college students in China. Shanghai Arch. Psychiatry 2016, $28,335-342$. [CrossRef]

14. Wang, X.; Hujjaree, K.; Wang, F. Mental Health Impacts for International Students during the COVID-19 Pandemic in China. Available online: https: / /assets.researchsquare.com/files /rs-49168/v1/14d3f52a-5b08-4503-8975-a607d88b387e.pdf?c=163184 7849 (accessed on 29 July 2021).

15. Li, Y.; Liang, F.; Xu, Q.; Gu, S.; Wang, Y.; Li, Y.; Zeng, Z. Social Support, Attachment Closeness, and Self-Esteem Affect Depression in International Students in China. Front. Psychol. 2021, 12, 618105. [CrossRef]

16. Gu, S.; Li, Y.; Liang, F.; Feng, R.; Zeng, Z.; Wang, F. The Mediating Effects of Coping Style on the Effects of Breath Count Mindfulness Training on Depressive Symptoms among International Students in China. Neural Plast. 2020, $2020,8859251$. [CrossRef] [PubMed]

17. Li, W.; Gillies, R.; He, M.; Wu, C.; Liu, S.; Gong, Z.; Sun, H. Barriers and facilitators to online medical and nursing education during the COVID-19 pandemic: Perspectives from international students from low- and middle-income countries and their teaching staff. Hum. Resour. Health 2021, 19, 1-14. [CrossRef] [PubMed]

18. Report on Nutrition and Chronic Diseases of Chinese Residents. Available online: http://www.scio.gov.cn/xwfbh/xwbfbh/ wqfbh/42311/44583/wz44585/Document/1695276/1695276.htm (accessed on 23 July 2021).

19. Kim, H.R.; Kim, E.J. Factors Associated with Mental Health among International Students during the COVID-19 Pandemic in South Korea. Int. J. Environ. Res. Public Health 2021, 18, 11381. [CrossRef]

20. Goodwin, G.M. The overlap between anxiety, depression, and obsessive-compulsive disorder. Dialog.-Clin. Neurosci. 2015, 17, 249-260. [CrossRef]

21. Nguyen, M.H.; Le, T.T.; Meirmanov, S. Depression, Acculturative Stress, and Social Connectedness among International University Students in Japan: A Statistical Investigation. Sustainability 2019, 11, 878. [CrossRef] 
22. Ertl, M.; Dillon, F.R.; Martin, J.L.; Babino, R.; De La Rosa, M. Alcohol use Exacerbates Acculturative Stress Among Recently Immigrated, Young Adult Latinas. J. Immigr. Minor. Health 2018, 20, 594-602. [CrossRef]

23. Paulus, D.J.; Rodriguez-Cano, R.; Garza, M.; Ochoa-Perez, M.; Lemaire, C.; Bakhshaie, J.; Viana, A.G.; Zvolensky, M.J. Acculturative stress and alcohol use among Latinx recruited from a primary care clinic: Moderations by emotion dysregulation. Am. J. Orthopsychiatry 2019, 89, 589-599. [CrossRef]

24. Park, C.; Spruill, T.M.; Butler, M.J.; Kwon, S.C.; Redeker, N.S.; Gharzeddine, R.; Whittemore, R. Gender Differences in Acculturative Stress and Habitual Sleep Duration in Korean American Immigrants. J. Immigr. Minor. Health 2020, 22, 736-745. [CrossRef] [PubMed]

25. Younis, I.; Longsheng, C.; Zulfiqar, M.I.; Imran, M.; Shah, S.A.A.; Hussain, M.; Solangi, Y.A. Regional disparities in Preventive measures of COVID-19 pandemic in China. A study from international students' prior knowledge, perception and vulnerabilities. Environ. Sci. Pollut. Res. 2021, 28, 40355-40370. [CrossRef]

26. Choi, Y.; Choi, S.-H.; Yun, J.-Y.; Lim, J.-A.; Kwon, Y.; Lee, H.Y.; Jang, J.H. The relationship between levels of self-esteem and the development of depression in young adults with mild depressive symptoms. Medicine 2019, 98, e17518. [CrossRef]

27. Hilbert, S.; Goerigk, S.; Padberg, F.; Nadjiri, A.; Übleis, A.; Jobst, A.; Dewald-Kaufmann, J.; Falkai, P.; Bühner, M.; Naumann, F.; et al. The Role of Self-Esteem in Depression: A Longitudinal Study. Behav. Cogn. Psychother. 2018, 47, 244-250. [CrossRef] [PubMed]

28. McConville, J.; McAleer, R.; Hahne, A. Mindfulness Training for Health Profession Students-The Effect of Mindfulness Training on Psychological Well-Being, Learning and Clinical Performance of Health Professional Students: A Systematic Review of Randomized and Non-randomized Controlled Trials. Explore 2017, 13, 26-45. [CrossRef] [PubMed] 